\title{
Cidade e Racismo: Clivagens na Cidade Colonial do Cabo
}

\author{
CABANILLAS, Natalia \\ Instituto de Humanidades e Letras-UNILAB-CE. Brasil. nataliacabanillas@gmail.com
}

\begin{abstract}
Resumo
O texto aborda como a racialização, a desigualdade e a diferença estruturam a paisagem urbana da Cidade do Cabo, capital turística e cultural. Analisa-se como a cidade é simbolizada, tensionando as heranças do seu binarismo colonial ${ }^{1}$ através de um itinerário linguísticohistórico. O texto nutre-se de observações etnográficas realizadas durante 18 meses na Cidade do Cabo (2014-2015) da pesquisa com mulheres ativistas. O artigo propõe um olhar para além e desde dentro das formas racializadas que estruturam a vida na cidade, sem por isso pretender obliterar, invisibilizar ou folclorizar a gritante desigualdade racial, de classe e gênero que é parte constitutiva da injustiça na África do Sul.
\end{abstract}

Palavras-Chave: Cidade do Cabo; Racismo; Ativismo de mulheres.

\begin{abstract}
This text discusses how racialization, inequality and difference structure the landscape of Cape Town, touristic and cultural capital. We analyze how the city is symbolized, stressing it's colonia $^{2} 1$ binarism heritage through a linguistichistoric path. The text is filled by ethnographic observations performed during 18 months in Cape Town (2014-2015) from a research with activist's women. The paper aim a regard beyond and through racialized shapes that structure city`s life, but without the intention of obliterate, make invisible or folkloric the huge racial, social and gender inequality, which is part of South Africa`s unfairness.
\end{abstract}

Key-Words: Cape Town; Racism; Women activism.

\footnotetext{
${ }^{1}$ Aqui o termo colonial está em cursivas para denotar seu uso como adjetivo, a continuidade com as formas coloniais de organização do espaço, moradia e formas de circulação na cidade. Não refere à temporalidade da colônia holandesa ou inglesa, se não, à persistência do regime de supremacia branca em diversos aspectos da vida da cidade.
}

\footnotetext{
2 The term colonial is used in here in italics to denote its use as an adjective, the continuity with the colonial forms of organization of the space, dwelling, and forms of circulation in the city. It does not refer to the temporality of the Dutch or English colony, if not, the persistence of the regime of white supremacy in various aspects of city life.
} 


\section{Introdução}

$\mathrm{Na}$ visão de visitantes críticos, sul-africanos ou brasileiros, a Cidade do Cabo é caracterizada como cidade branca. Esta forma de enunciá-la, oblitera a dependência que a [parte branca da] cidade tem em relação aos/às trabalhadores/as não brancas, habitantes dos townships ${ }^{3}$ nos Cape Flats (área periférica) que diariamente batalham para sobreviver ocupando subempregos na cidade. A Cidade do Cabo constitui uma unidade de diversas formas de dependência e coexistência forçada (NUTTAL, 2007) ${ }^{4}$ entre o centro branco ou as áreas de residência privilegiadas, e as planejadas para ser cidades dormitório.

Assim, chamo preferencialmente a Cidade do Cabo como uma cidade de caráter ou atributos coloniais, pelas características espaciais e pela forma na qual estrutura-se a circulação de corpos, serviços e recursos. Frantz Fanon (1983) definiu a cidade colonial como uma cidade dual ${ }^{5}$ que articula a ultra-segurança e máxima provisão de recursos nas áreas brancas com as áreas de residência da população não branca, com mínima disposição de serviços, recursos e facilidades, afastadas dos centros embranquecidos de poder por longas autovias. The Cape Colony - a colônia do Cabo - é a forma na qual ativistas e intelectuais radicais chamam a cidade hoje nas suas críticas nas redes sociais, nas crônicas do existir-resistindo, ou resistir para existir. A cidade colonial, compreende uma unidade indivisível, onde a visível, publicizada e ostentosamente linda Cape Town tem sua contrapartida nas áreas segregadas nos Cape Flats: populosas, fragmentadas e feridas.

Apesar da negação ou da homogeneização semântica operada sobre os Cape Flats, a hiper heterogeneidade (ALHOURANI, 2015), diversi-

\footnotetext{
${ }^{3}$ Localmente, chama-se de township, location ou kasi, aos bairros negros, antigamente classificados como "africanos" pelo apartheid. $\mathrm{Na}$ Cidade do Cabo, as moradias das townships continuam a ser maioritariamente de papelão e outros materiais precários; não possuem instalações elétricas formais ou tomadas de agua dentro da casa.

${ }^{4}$ Neste texto coloco as referências com nome e sobrenome para destacar o gênero das autoras citadas. Assim mesmo, cito com o mesmo estilo estudos acadêmicos e entrevistas, entendendo que oralidade e produção escrita são duas formas de produzir conhecimento igualmente teórico.

${ }^{5}$ Fanon utiliza o termo dual para descrever a Argelia colonial, termo que hoje seria suplantado pelo conceito "binario".
}

dade e encontro de temporalidades obliteradas caracterizam as townships e suas tensões são experimentadas como inerentes e cotidianas. Assim a vivência da cidade colonial, com o centro branco da Cidade do Cabo e os Cape Flats Negros (bairros africanos, mestiços/coloured ou indianos ${ }^{6}$ ), é um binarismo reforçado pelo apartheid, que não resume nem contempla um sem número de deslizes de sentido, histórias, lutas e identidades que operam em fragmentos, mas ao mesmo tempo funcionam de modo articulado. Um dos níveis de fragmentação e articulação são as línguas historicamente situadas, nas quais se produz existência, pertencimento e comunidades nos Cape Flats. Sobre essa questão trata o apartado clivagens III.

A Cidade do Cabo compreende tanto as áreas branqueadas $^{7}$ : centro [Town], os subúrbios residenciais do Sul, a franja costeira ao longo do Oceano Atlântico; quanto os Cape Flats, área periférica [townships] da Cidade onde reside população Negra. A imbricação e dependência entre ambas, encontra-se quebrada espacial, cultural, racial e arquitetonicamente, de tal forma que a Cidade do Cabo raramente é referenciada como essa unidade interdependente. A clivagem racial que torna a cidade binaria, não resume, compreende ou explica a diversidade das townships, as formas de transitar, habitar e experimentar a cidade em sentidos contra hegemônicos.

\footnotetext{
${ }^{6}$ Emprego aqui a definição Negra em maiúsculas para me referir a todas as pessoas antigamente classificadas como africanas [African], coloured [mestiças], ou Indianas [Indian] pelos diversos regimes racistas que governaram a atual África do Sul entre 1652 e 1994. Tal agrupamento vem da politização proposta nos anos 70 e 80 pelo Black Conciousness Movement para se referir a todas as pessoas não privilegiadas pelo regime do apartheid e que estivessem dispostas a lutar contra a supremacia branca. Quando escrevo negra em minúsculas é para me referir a população que hoje se autodeclara negra e/ou africana, pertencente a alguns dos grupos indígenas do continente africano. Tanto a categoria negro/a [black] como Africana/o [African] tem diversos significados, ambivalências e apropriações a partir do Estado e a partir da população. A população classificada como European e referida como branca neste texto compreende grupos falantes de afrikaans descendentes de colonos holandeses e grupos anglófonos descendentes de colonizadores, principalmente.

${ }^{7}$ Comumente chama-se estas áreas de brancas [White], o que foca no resultado e apaga o processo violento de branqueamento com políticas racistas higienistas pré-1994 e com a gentrificação atual. Apaga também o continuum de disputas: a população de rua que habita as White áreas; os africanos estrangeiros que alugam pequenas ou grandes residências, etc.
} 
O planejamento da Cidade do Cabo como cidade colonial sob a lógica da separação racial aprofundou-se durante o apartheid (1948-94) ${ }^{8}$ norteado pelo princípio de zoneamento; desenvolveu-se um urbanismo modernista ao serviço do projeto ultra racista do governo da minoria branca do National Party, onde a engenharia social procurava reduzir ao máximo possível os pontos de contato entre as zonas (racialmente definidas a través da Lei de Áreas de Grupos, de 1950). Assim, a redução dos pontos de contato a sua mínima expressão constitui o que Fanon $(1983$, p. 18) chamou de "mundo em compartimentos".

O ano das primeiras eleições democráticas universais no país, 1994, marca simbolicamente a derrota do apartheid em termos jurídicos (abolição de leis racistas entre 1990-94) e políticos (extensão do direito ao voto a toda a população). No entanto, a continuidade das desigualdades raciais, econômicas, urbanistas, e de gênero na Cidade do Cabo são enormes. Tal continuidade estrutura-se por um lado através da inércia do regime de supremacia branca: nas formas de habitar o espaço e pela articulação entre desigualdade racial e de classe; e por outro através de novas formas de estruturação racista da cidade: iniciativas empresariais de gentrificação ${ }^{9}$ e políticas higienistas do governo do Democratic Alliance ${ }^{10}$ na província do Cabo

\footnotetext{
${ }^{8}$ Em 1950, o apartheid implementou a classificação racial compulsória utilizando o Censo de 1951 para tal fim (Lei de Registro da População $n^{\circ} 30$ ). Tudo o que um ser humano podia ou não fazer dependeria da classificação racial, e seria regulado com inúmeras leis discriminatórias: Onde poderia morar (Lei de Áreas de Grupos), com quem poderia casar (Lei de Proibição de Matrimônios Mistos), ou ter relações sexuais (Lei de Imoralidade), a que escola poderia ir (Lei de Educação Banto), quais eventos poderia assistir (Lei de Entretenimentos Separados), dentre outras.

${ }^{9} \mathrm{Na}$ África do Sul, a gentrificação é operada pelo planejamento privado com o aval governamental: uma companhia desenvolvimentista compra uma área completa considerada "degradada", usualmente no centro da cidade. Investe em restauração de edifícios e aumenta de forma abrupta e unilateral os preços dos aluguéis, obrigando aos moradores/as antigas e pobres a mudar ou vender. O governo promove os desalojamentos forçados nos casos em que os residentes não possuem proteção legal para permanecer (propriedade ou contrato de aluguel). $\mathrm{O}$ bairro renovado $\mathrm{e}$ caríssimo tem como parte da sua valorização a áurea de ser [ter sido] uma área comunitária. A gentrificação vende também o conceito do tradicional e comunitário, seu revestimento modificado, enquanto a vizinhança que criou tal tipo de convivência é maiormente expulsa das áreas e não participa em nada dos dividendos da gentrificação.

${ }^{10}$ Democratic Alliance é o partido que governa a província do Western Cape e a Cidade do Cabo desde 2009; surgiu
}

Oriental tais como expulsões forçadas de população pobre Negra das áreas residenciais embranquecidas, instalação de moradia temporárias tipo acampamento ou de moradia social em áreas extremamente distantes do centro, e descaso generalizado em torno a falta de casa para população pobre e para provisão de serviços nas townships.

\subsection{Territórios: desafiando os fragmen- tos}

Cape of Tears, Cape of Death, Cape of Struggles ${ }^{11}$ [O Cabo das Lágrimas, O Cabo da Morte, O Cabo das Lutas]

A segmentação do território foi a forma como o racismo institucionalizado codificou a vida cotidiana, colonizou e re-colonizou o espaço, atribuindo-Ihe sentidos, valores e possibilidades. $O$ apartheid estabeleceu áreas de moradia separadas, destinadas às comunidades European, Indian, Coloured [mestiço/a] ou African ${ }^{12}$, geograficamente delimitadas por avenidas, trilhos do trem, canais ou áreas verdes, mais ou menos distantes do centro branco dependendo da classificação racial. ${ }^{13}$ Cada área, ademais, seria

da oposição parlamentária dentro do apartheid, sendo por tanto, considerado um partido branco. O DA defende visões tecnocratas, liberais e cujos efeitos mantém amplamente o regime de supremacia branca na província, especialmente no que se refere a segregação espacial. Western Cape é a única província que não é governada pelo ANC - partido negro nacionalista que lidera a política sul - africana desde o derrubamento do apartheid.

${ }^{11}$ A frase pertence a CRISTIANSEN, (2006:66), citada em Gabeba BADEROON (2015:98). A mesma dialoga em intertexto com a narrativa dominante: o Cabo da Boa Esperança e o Cabo das Tormentas. Ambos representam o ponto de vista do colonizador, o Cabo como estação de reabastecimento, a circunavegação do continente, e a fúria do encontro das águas e ventos do Oceano Atlântico e Índico.

${ }_{12} \mathrm{O}$ apartheid definiu quatro categorias raciais principais; duas delas por pertencimento continental: Africano/a e Europeu/ia, correspondendo na vida quotidiana às categorias de negro/a e branco/a respectivamente. Indiano/a para a população descendente de indianos/as, muitos deles/as levados/as à África do Sul para trabalhar em condições de escravidão; e coloured ou mestiço para se referir a toda a população que não encaixaria como Branca ou Negra. A população coloured é talvez a mais contestada por conter na sua definição a noção de mistura, proibida pelo apartheid como imoral. A população mestiça local descende de asiáticos/as que foram escravizados/as nos séculos XVII-XIX, dos estupros sistemáticos perpetrados pelos donos brancos de escravizadas provenientes do leste do continente, do sul (khoi-san) e de diversas partes da Ásia.

${ }^{13}$ Durante o trabalho de campo na Cidade do Cabo não tirei fotografias, escolhi reproduzir e referenciar formas de autorrepresentação: fotógrafos/as, documentaristas, cantoras/es de hip hop. Para o caso da paisagem das áreas coloured, 
(des)provida de uma determinada quantidade de infraestrutura e serviços em conformidade com uma classificação racial previamente ponderada, com autorização para a construção de determinado tipo de moradias e proibição para autoconstrução ou modificação das mesmas (MCELEZILE, 2015).

Assim, o apartheid produziu os grupos raciais jurídica e espacialmente, criou a homogeneização visual da paisagem racializada plasmada em um tipo particular de arquitetura: hostels e shacks $^{14}$ nos bairros africanos; as cortes (prédios de 3 andares com apartamentos de um quarto) ou casas com jardins nos bairros coloured; e casas de até 4 quartos nos segmentos destinados à população indiana. Enormes casas e cabanas vitorianas de até 8 quartos nas áreas delimitadas como europeias. A produção da estandardização arquitetônica tem um correlato com a criação de sujeitos jurídicos racializados $^{15}$ : African, Indian, Coloured, European, estabilizada durante séculos de colonialismo e endurecido nas décadas do apartheid.

As formas nas quais a temporalidade do apartheid invade, permeia e impregna a vida cotidiana da cidade se estabelece em vasos comunicantes com estrita diagramação espacial. Por isso, as formas de atravessar a cidade geográfica, espacial e emocionalmente não podem ser senão fragmentadas, acidentadas, quebradas, e ao mesmo tempo sedimentada, com a experimentação simultânea de vários mundos. Localizada, no Cabo das Lágrimas.

O centro da Cidade - Town $-^{16}$ possui vias de

compartilho aqui duas produções de Hip Hop: "Terror MC Liberate yourself". https://www.youtube.com/watch?v=ITKFBPM4GNg; e uma estética diferenciada no olhar artístico de Dope St Jude: "Jazarin Xxplosive" e "Angel Ho- Keep in Touch" https://www.youtube.com/watch?v=tGufiZ4BXZM https://www.youtube.com/watch?v=w2ux9R839|

${ }^{14}$ Hostels são grandes galpões com camas destinados aos trabalhadores migrantes (homens solteiros) nas minas ou na cidade, tendo uma cama como todo espaço pessoal (Ramphele, 1993); as shacks são casas de cmmpensado e papelão, sem instalações sanitárias nem de água, ou eletricidade. Homens casados tinham acesso a essas casas, porém as listas de espera eram intermináveis.

${ }^{15} \mathrm{Na}$ produção jurídica de sujeitos racializados existem diferenças de gênero, já que a infantilização jurídica das mulheres africanas é mais acentuada que nos homens.

${ }^{16}$ No presente texto não analiso Century City. A mesma compreende 20 hectares nas redondezas da Cidade do Cabo, destinados a empresas privadas e negócios. O proje- comunicação, limpeza, eletricidade e iluminação, água potável, segurança; serviços de transportes públicos (trem, ônibus e kombis) concentram-se na estação central, assim como escritórios de governo, comercio, etc. As áreas geográficas próximas ao centro, seja em direção ao sul ou ao longo da costa atlântica, foram maiormente reservadas por lei para moradia da população branca, classificada como Europeia. A população negra, mestiça ou indiana foi desalojada pela força policial por esse motivo.

Os Cape Flats, em termos de geografia física, são uma planície arenosa estendida por "trás" de Table Mountain, símbolo da Cidade do Cabo. Nesta área, a população Negra foi localizada forçadamente e agrupada em townships. As áreas classificadas como Indianas e coloured possuem hoje em dia água encanada dentro de casa, saneamento básico, e eletricidade prépaga. Enquanto nas áreas antigamente classificadas como Africanas, o acesso a eletricidade é maiormente informal, a calefação é feita com parafina, aumentando o risco de incêndio; a maioria das famílias compartilha uma torneira de água externa e sanitários químicos públicos; com mais de 20 anos de fim do apartheid, nas townships da Cidade do Cabo ainda predominam amplamente as casas de metal e papelão (shacks) sobre as casas de alvenaria. ${ }^{17}$

As áreas delimitadas pelo apartheid para Africanos foram construídas sob a lógica militarista: cercadas com poucos pontos de acesso e saída, com traçado quadricular, facilmente controlável desde os helicópteros; as moradias ou shacks estão cercadas e separadas das aveni-

to queria erradicar a atividade econômica do centro da cidade uma vez que o aceso ao mesmo tinha sido "democratizado" desde 1994. A iniciativa não foi bem sucedida como foi em Johannesburgo, onde a iniciativa privada abandonou literalmente o centro da cidade. Não obstante, Century City constitui uma grande tentativa de reracialização da vida e manutenção do privilégio branco através da segregação espacial.

${ }^{17}$ A fim de acompanhar visualmente o relato, recomenda-se assistir o vídeo de Hip Hop de Java, "In my Bag", dirigido por Sandiswa TSHEFU, no bairro onde ela mesma mora, em Town 2 (Informal Settlement), na township negra Khayelitsha.

https://www.youtube.com/watch?v=M9mCjYH4m_4\&feature =share Sandiswa é uma jovem diretora de cinema, originária de Port Elizabeth. É possível observar o contraste estético com a forma de filmar o documentário de Ndifuna Kwazi referido na bibliografia. 
das ou autopistas por espaços baldios de 60 metros. Calcula-se que 60 metros é a distância máxima que alcançaria um objeto lançado por um ser humano (WAINWRIGHT, 2017). Assim, as forças de segurança conseguiriam patrulhar as áreas Negras em veículos blindados (caspirs) a uma distância prudencial que não permitia ser atingidos por pedras ou bombas molotoves lançadas das áreas de casas nas épocas de maior resistência ao apartheid. A infraestrutura como as autovias já foi construída sob a hipótese militarista de um conflito desigual. Ao mesmo tempo, as avenidas rodeadas de mato constroem a paisagem da desolação, característica dos Cape Flats, assim como a hostilidade que representa para as mulheres a existência de grandes espaços sem iluminação nem casas a ser atravessados cada vez que é preciso pegar transporte público.

O regime de supremacia branca criou as townships para serem espaços de moradia hostis e difíceis: sem serviços nem áreas de recreação, distantes das áreas de trabalho, com proibição da autoconstrução e de compra de propriedades em muitos casos (ROSS, 2010; ROSSOUW, 2015); conforme Elaine Salo (2003; 2004) construir comunidades é uma reinvenção das fronteiras (impostas pelo apartheid) e das formas de pertencimento. A comunidade é -entre outras coisas - uma rede que garante o acesso a recursos, ajuda, informação, controle social e proteção; garante um regime de produção de autoridade e de existências. É uma forma particular de viver, habitar a township, uma forma de humanizar, familiarizar e proteger um espaço, abandonado a sua própria sorte. Transitar, O Cabo do Medo.

A comunidade constitui um lócus de enunciação legítima da política, como se a comunidade fosse uma fábrica de autenticidade. Não é sinônimo de township, muito menos de um grupo racial: é uma rede estendida e delimitada territorialmente através de laços de reciprocidade, ajuda mútua e controle, principalmente entre mulheres, e ativada através de relações interpessoais geracionalmente estruturadas. A palavra e conceito community, é usada frequentemente tanto em townships mestiças como afri- canas e, como tal, é polivalente. Remete a um lugar de pertencimento social, geográfico, mas também emocional e político. Talvez seja uma forma feminizada de construir poder na contracorrente da lógica necropolítica (MBEMBE, 2011).

No entanto, é a comunidade e não a township o que define a unidade territorial. Elaine Salo (2003) problematiza a construção de microcomunidades na township mestiça de Manemberg, dentro das quais as atividades de cuidado das mulheres adultas, normas de moral, decência e pertencimento cobram sentido (2003, p. 351). Cada comunidade é organizada através de redes de vizinhança femininas, com limites conhecidos para os/as integrantes e regiões vizinhas. Conforme Salo (2003), os homens delimitam fisicamente o espaço de uma comunidade através de práticas de gângsters (assassinato e estupro). Em uma releitura da autora, poderia se dizer que os integrantes das gangues respeitam os limites da comunidade onde habitam (estabelecida a través das políticas de cuidado das mulheres), e exercem seu poder para além de tais fronteiras.

Assim como as comunidades produzem uma forma de existir no espaço, tem também o poder de criar existência, e de delimitar quais corpos tem direito a existir: seres humanos definidos arbitrariamente como não pertencentes às comunidades são objeto de violência letal ${ }^{18}$. Durante a luta contra o apartheid, a comunidade definia-se principalmente em termos políticos e boa parte dos assassinatos públicos e coletivos eram dirigidos contra pessoas suspeitas de serem espiões da polícia. O exercício da necropolítica (MBEMBE, 2011) - a criação de soberania através do poder de matar - opera na eliminação pública e cruel de estrangeiros e população LGTBI (MATEBENI, 2015), corpos codificados como "aliens" "unafrican" (THAFENI, 2015; MANRUPTING, 2015; GQOLA, 2008). Este tipo de assassinatos expressivos (SEGATO, 2004) inscreve-se nos cenários montados para "deixar morrer os corpos negros": as

\footnotetext{
${ }^{18}$ Agradeço a Antonadia Borges por ter colocado esta crítica sobre meu trabalho, trazendo quanto o conceito de "community" está longe de ser uma ideia e prática romantizável.
} 
townships (NCEDILE, 2015: declaração pública); análogo ao que Achille Mbembe (2011) chamou de "campos de morte", onde predomina a linguagem da violência (DEYI, 2015). Os assassinatos públicos de determinados corpos negros codificados como objetos e alheios [aliens] as comunidades, não constitui uma exceção, senão a expressão última de um continuum de formas necropolíticas de construção do poder no regime de supremacia branca. Sobreviver, no Cabo da Morte.

Para todas as ativistas com quem me relacionei, a comunidade é prioritária: se assemelha a um investimento, é como ter uma conta no banco, a garantia da sobrevivência e de existência: "Eu sou rica em pessoas" (HARNECKER, 2015: conversações). A forma de nutrir as comunidades é através das ações de ajuda e de dar amor, conselho, comida, recomendações, contatos, trabalho (MAKAN, 2015; HARNACKER, 2015; CLAASEN, 2015). Construir comunidade na paisagem ferida do Cabo é uma forma de existir-resistir; uma forma de construir poder, um poder que não é necropolítico e que não se define pela acumulação de bens ou serviços, mas pela acumulação de relações humanas, nutridas emocionalmente e intensamente recíprocas. É uma aposta por viver através de outros seres humanos ${ }^{19}$. Re-existir, No Cabo das Lutas.

\section{Clivagens da Cidade Colonial do Cabo}

A Cidade do Cabo tem como seu emblema central a Table Mountain; símbolo representado principalmente a partir do oceano Atlântico, como indica Heidi Grunebaum (2004), desde o ponto de vista de uma nave que se aproxima da terra, o ponto de vista do colonizador: o mar, a praia, terra firme e a montanha. $O$ interior do continente é um vácuo, um além da montanha, indistinguível, invisível desde o mar. Esse invisível desde o Atlântico são os Cape Flats, que

\footnotetext{
${ }^{19}$ Aqui estou apenas me referindo às noções de comunidade para as mulheres, que a constroem sem o poder das armas. Não me aventuro a estabelecer como é a relação entre a construção de comunidades desarmadas feminizadas baseadas na economia política do cuidado e o exercício do poder necropolítico por homens jovens no "para além" das fronteiras das suas comunidades.
}

dão de costas à Table Mountain e de cara ao Oceano Índico, na eterna lembrança da diáspora indiana e malaia.

Na mídia, os Cape Flats são sinônimo de crimes e devastação, uma sorte de subúrbios esquecidos que participam bem pouco do glamour da encantadora Cape Town. Nessas inscrições, os Cape Flats são definidos pela exclusão e, nessa homogeneização semântica, são o reverso - o Outro negado - da Cidade do Cabo, autoproduzida e propagandizada como cidade moderna, turística e de belezas entranháveis (MKHOSI, 2015: documentário). A mídia foca na criminalidade, por enquanto ONGs de diversos tipos produzem também os Cape Flats como áreas desvalidas, na construção de denúncias e procurando atrair a atenção do governo e dos doadores internacionais (KWASI, 2014: documentário). Grunebaum (2007) e Gabeba Baderoon (2015) coincidem em apreciar que a Cidade do Cabo e a sua presumida beleza descansam sobre - literalmente foram construídas como trabalho escravo durante a colônia; a exploração econômica da população Negra; e mais recentemente tal "beleza" assenta-se sobre as erradicações forçadas de população e recente gentrificação, e sob o trabalho ultra explorado da população africana migrante que presta serviços nas áreas brancas da cidade.

\subsection{Clivagem I: O Medo}

Cercas eletrificadas, alarmes, arame estilo "campo de concentração" separam as residências brancas de classe média alta de uma rua pública que -presume-se- perigosa. As muraIhas marcam a fronteira material, e nelas inscreve-se a ameaça: "Resposta armada" anunciam os cartais de segurança privada (Foto 2). As ruas dos subúrbios brancos, são maiormente vazias, já que a os/as moradores/as possuem carros. Apenas as pessoas [Negras] que trabaIham na área e moradores/as de rua são corpos que andam a pé. As áreas de escassa circulação são constitutivas da vulnerabilidade dos corpos femininos e feminizados sem carro, e que vivem [vivemos] o terrorismo de gênero: a quotidiana ameaça de estupro, em palavras de Pumla Gqola (2015), a fábrica do medo feminino (Zanele MUHOLI, 2013: documentário). 
O medo vira o articulador semântico da experiência da cidade, e na sua lógica racista inverte o sentido do risco (Foto 1). Os corpos brancos marcados como invioláveis, moram cercados de certezas e seguranças mercenárias, em nome de uma potencial imaginada ameaça. Os corpos Negros marcados como perigosos, viram alvo móvel, suscetível de ser alcançado por uma resposta armada: a criminalidade imaginada dos corpos Negros abre caminho a criminalidade de fato da segurança paga para proteger as áreas brancas, através das ameaças de morte. A insegurança imaginada de "dentro das casas" é jogada para fora: o espaço público acaba sendo dominado pela ameaça da violência, por aquelas empresas que prometem proteger as propriedades privadas das classes média-alta, com a possibilidade de morte dirigida a corpos estigmatizados como criminosos potenciais. No entanto, o medo possui também poder de agencia: esvazia os espaços urbanos e, reforça a vulnerabilidade de quem quer ou precisa caminhar.

Não obstante, o reino do medo branco não tem relação necessária com as estatísticas. É verdade que a África do Sul é conhecida por ser um país com alta prevalência de violência e assassinatos. No entanto, a maior quantidade de crimes contabilizados estatisticamente ${ }^{20}$ acontece nas townships: áreas de residência Negra separadas do centro da cidade por longas avenidas autopistas. Nas townships, a segurança pública é ínfima: Khayelitsha é uma township localizada a $25 \mathrm{~km}$ do centro da cidade, e que conta com uma única estação de polícia (Site B) para um milhão de habitantes; a iluminação pública é extremamente precária e limita-se às vias principais; o sistema de transporte coletivo é maioritariamente autogestiona-

\footnotetext{
${ }^{20}$ Por exemplo, a amplitude de um crime como a corrupção não necessariamente entra na contabilidade criminosa; no entanto, uma enorme quantidade de famílias vive e morre sem aceso a serviços básicos porque o dinheiro para obras públicas é sistematicamente desviado. A falta de água potável define entre a vida e a morte da população Negra; a ausência de banheiros nas casas aumenta o risco de sofrer ataques sexuais durante a inda ou volta ao banheiro público nas townships sem iluminação pública, e assim em diante. A gentrificação que promove o desalojamento pela força e relocalização da população de rua e o acionar policial obedecendo tais leis para "limpar" áreas brancas também não conta como ato criminoso estatisticamente falando.
}

do com práticas do tipo mafiosas (sistema de kombis) e sem segurança estatal alguma (como o trem). Assim como em outras townships, a organização de segurança comunitária [desarmada] Neighbourhood Watch patrulha a pé durante a noite para diminuir o número de roubos e estupros. Garantem: apitos, correria, exposição social e, às vezes, seguida de entrega do suspeito à polícia, ou de uma potencial vingança comunitária (CLAANSEN, 2015).

Moradores/as de Khayelitsha não duvidam em chamar as townships de "campos de concentração" (Residente de Site B, Khayelitsha) "Campos criados pelo regime de supremacia branca destinados a deixar morrer os corpos negros" (Residente de Harare, Khayelitsha, 2015). A violência do crime que acontece dentro das townships está estreitamente relacionada com as condições de vida dentro das mesmas e a dolorosa continuidade do apartheid, desdobrando os sentidos de alienação da população local negra a respeito da terra e da paisagem do Cabo.

"Quando fala do colonizado, a linguagem do colono é sempre uma linguagem zoológica" (FANON, 1983, p. 20). [tradução própria]

Figura 1: Anúncios da companhia "Segurança Selvagem" em Mowbray, Southern Suburbs, Cidade do Cabo. A S inicial em forma de raio, remete a potencial descarga eléctrica dos 6 fios acima; e relembra a iconografia das SS nazistas. Não sabemos se a segurança oferecida é selvagem, pela desproporcionada crueldade que é capaz de causar, promessa de ser implacável contra os corpos codificados como perigosos; ou se é segurança contra "os selvagens", formas racistas em que a população negra foi estigmatizada pelos regimes de supremacia branca e seus/suas defensores.

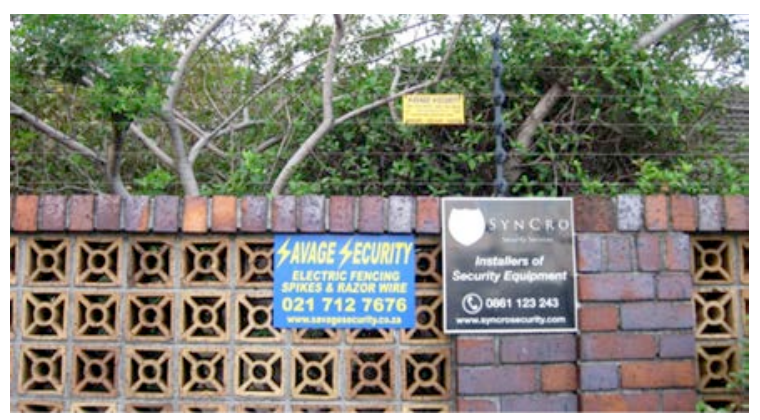

Crédito da Foto: Germán Montoya.

"A cidade do colono é uma cidade dura, de pedra e ferro" (FANON, 1983, p. 18) [tradução própria]" 
Figura 2: Anúncio de Resposta Armada, Empresa ADT, em casa em Mowbray, Southern Subrubs, Cidade do Cabo. Uma vez que as cidade brancas são de livre circulação desde 1994, a fronteira colonial é reinventada com muralhas e ameaças de morte, pagando-se mercenários da segurança privada.

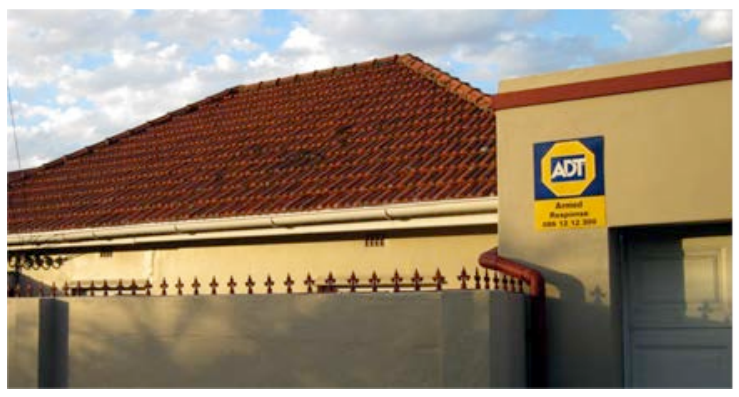

Crédito da Foto: Germán Montoya.

\subsection{Clivagem II: Cidade Mães}

Nos anúncios turísticos, e nas visões romantizadas, a Cidade do Cabo é carinhosamente apelidada como a Cidade Mãe [Mother City]. $\mathrm{Na}$ revista online de atividades turísticas "Cape Town Magazine" aparece um artigo questionando o apelido. Indica como possível origem a Cidade do Cabo ter sido consideradava primeira metrópole na década de 30; o fato do vocábulo "Mother" ser usado muitas vezes por dia nas línguas locais; e finalmente "porque qualquer tarefa na Cidade do Cabo demora nove meses para dar certo" retomando o estereótipo de ser uma cidade de ritmo lento, quando comparada com a frenética Johannesburgo. A nota pretende-se simpática e em nenhum momento passa do anedotário, dá por certo que a Cidade do Cabo foi a primeira cidade do Sul do continente (CAPE TOWN MAGAZINE, Sem data).

Quando fala-se de Mother City ou Cidade Mãe, implicitamente, refere-se a parte branca da cidade: ao centro e áreas de restaurantes, shoppings, Galerias de Arte e costa Atlântica. Seria nesta visão a Cidade de origem, o primeiro assentamento urbano do que hoje é a África do Sul; como se os assentamentos não urbanos/ urbanizados, não fossem humanos o suficiente para fundar uma origem. Antes da Colônia do Cabo existir, o continente era povoado por grupos indígenas Khoi San; posteriormente receberiam ainda as migrações de povos banto provindos da região dos Grandes Lagos (África Oriental).

O primeiro povoamento branco na região foi a colônia holandesa que se estabeleceu em 1652 no Cabo da Boa Esperança. Apenas 6 anos depois, um contingente de soldados escravizados é trazidos da Malásia. Tal população seria condição para a radicação holandesa branca no extremo sul do continente, e instrumental na guerra de conquista contra a população local. Cidade Mãe: Mãe da Escravidão, Mãe da Guerra de conquista e Mãe da Expropriação das terras.

No entanto, a categoria Mãe é uma das mais respeitadas: invoca poder e respeito ao mesmo tempo; emerge de formas africanas de estrutura familiar e se reproduz na vida política, social e cotidiana da população não branca da Cidade do Cabo e da África do Sul. A maior organização de mulheres da área, Mustadafim Foundation, organiza todas duas intervenções em função de atividades de cuidado baseadas em ideologias e práticas de maternagem social. $\mathrm{O}$ apelido carinhoso Cidade Mãe, Mother City, invoca tanto a temporalidade colonial quanto um dos marcadores socialmente mais relevantes de poder e prestígio no ethos local: a maternidade.

\subsection{Clivagem III: Re-existir em línguas}

Mustadafin Foundation (MF) ${ }^{21}$, organização islâmica de mulheres, é uma das maiores da província do Cabo Ocidental, em função da quantidade de pessoas que impacta, o seu orçamento anual, a diversidade de áreas que abarca e o trabalho de integração que realiza, assim como o impacto na vida real das mulheres de base. ${ }^{22}$

No informe anual de Mustadafin Foundation

\footnotetext{
${ }^{21}$ Mustadafim Foundation é uma das três organizações com as quais me vinculei durante um ano e meio de "trabalho de campo" na Cidade do Cabo. Me integrei como voluntária da organização, coordenando uma oficina de expressão corporal para integrantes de Mustadafin, desenhada junto com a diretora no viés de políticas de autocuidado das ativistas de Mustadafim. Todas as integrantes são sobreviventes de diversas formas de violência, e vivem nas townships coloured ou africanas.

${ }^{22}$ Conforme Ala Rabiha AlHourani (resultados parciais de pesquisa, em conversações informais, 2015), Mustadafim Foundation impacta em 100,000 pessoas por mês, contabilizando todos seus programas estáveis de saúde, alimentação, desenvolvimento comunitário, e da juventude. Apenas o programa de alimentação alcança 15,000 pessoas por dia, sem contar os programas especiais dirigidos a famílias com integrantes com doenças terminais, programas de maternidade social e atenção em catástrofes. Seu orçamento anual em 2014-15 foi o equivalente à 8 milhões de reais.
} 
(Ramadan Feedback, 2015), a primeira página está dedicada às palavras da diretora Ghairunisa Johnstonne Cassiem. Tem uma foto dela tipo identidade, sorrindo e com scarf ${ }^{23}$ verde. Abaixo em letras roxas diz: "Shukran, Dankie, Thank you, Enkosi". Obrigado nas quatro línguas em que a organização trabalha: Árabe [transliterado], Afrikaans, Inglês e isiXhosa, respectivamente. Partindo apenas da forma em que a maior organização da província agradece no seu informe anual pode-se destecer histórias contidas nos vocábulos, sedimentadas ao longo de séculos de colonialismo, parte desse solo arenoso, instável e volátil dos Cape Flats: de longe uma massa homogênea e descolorida, de perto uma multiplicidade de partículas brilhantes, dinâmicas, inassimiláveis, justapostas, parecidas e diferentes ao mesmo tempo.

Shukran é uma das muitas palavras em árabe que são usadas - ou conhecidas - nas comunidades mestiças [coloured] e indiana da Cidade; tanto quanto, Salaam Aleykum- Aleykum Salaam cumprimento diário; Insha-Allah/mashaAllah (se Deus quiser), Al-hamdulillah (que Deus seja louvado), Halal (permitido pelo Alcorão), Ramadán (mês lunar sagrado), Eid Mubarak (Feliz ano novo). A Constituição (1996) do país reconhece o Árabe, o Hebreu e o Hindi como línguas de culto, além das 11 línguas oficiais. Todos os nomes de rituais, as rezas e o vocabulário religioso do islã são em árabe. O Alcorão - livro sagrado e o verbo de Deus - não se traduz, e como tal, toda pessoa muçulmana terá algum contato com o árabe, com sua grafia e sobretudo, com seu $\mathrm{som}^{24}$. A sonoridade do árabe tece tanto o pertencimento a uma história local de luta e diáspora, quanto o pertencimento à Ummah, comunidade muçulmana, de inscrição global.

As palavras em árabe mais conhecidas estão

\footnotetext{
${ }^{23}$ Se denomina wearing Scarf, usar o véu, mesmo que o scarf se traduziria como cachecol. Hijab é o que se conhece como véu islâmico. Na Cidade do Cabo, a população sul africana islâmica utiliza majoritariamente um ou dois lenços (scarf) para cobrir o cabelo. Algumas vezes adquire a mesma forma que o doek.

${ }^{24}$ As Suras do Alcorão são recitadas/cantadas na mesquita e as rezas são também em árabe. O som transpassa os muros das mesquitas e sua textura inunda as mediações, principalmente durante as festividades e nas rezas ao amanhecer, quando a cidade ainda está em silêncio.
}

na esfera das interações cotidianas face a face: utilizadas em todos e cada um dos encontros entre pessoas muçulmanas: oi, obrigada, que Deus assim queira. Desta forma existe um enactment da comunidade, uma produção sonora do pertencimento, através do reconhecimento mútuo e da autoafirmação; as formas de produzir a existência islâmica na Cidade do Cabo inclui as expressões em árabe e sua sonoridade nos registros auditivos de uma cidade multilíngue; a vestimenta (Taqiya e kurta [bui-bui] para os homens, scarf [hijab] o véu para as mulheres, camisolas e vestidos de desenho islâmi$\mathrm{Co}^{25}$; a comida Cape Malay ${ }^{26}$, seus ingredientes e seus circuitos de produção e certificação halaal; o acompanhamento do calendário islâmico, na performance local de rituais em simultaneidade com a Ummah global. Assim, as comunidades muçulmanas ${ }^{27}$ da Cidade do Cabo se

\footnotetext{
${ }^{25}$ A roupa islâmica de mulher tem um desenho e estética particular. Ao descrevê-la não necessariamente apareceria em palavras como diferente da roupa local de mulheres cristãs Negras. Localmente a maioria das mulheres Negras cobrem a cabeça, mas a scarf islâmica é cobrir os cabelos com uma elegância e estilo distintivo, que não é assimilável ao doek das operárias e donas de casa coloured nem ao estilo xhosa de mulher mais velha ou makoti [recém casada/recém lobolada]. O tipo de tecido, além do desenho do pano na cabeça distingue uma prática da outra. No entanto, não é fora do comum ver empréstimos entre umas e outras. Por outro lado a roupa masculina, os kurta locais são de cores neutras: branco, cinza, marrom e preto, como as taqiyas. No máximo essas últimas são bordadas. Os migrantes muçulmanos da África ocidental vestem em ocasiões especiais roupa estilo kurta, calça e túnica de tecidos africanos, cores contrastantes, nesse sentido, mesmo que de similar desenho, a textura e cor dos tecidos definem na Cidade do Cabo um pertencimento religioso e nacional. Ainda assim, dentro da vestimenta islâmica, as e os migrantes introduzem elementos particulares não assimilados: as visitantes da Arábia Saudita possuem um estilo de véu diferente, assim como as migrantes da Somália, cuja peça, usualmente de uma única cor brilhante, cobre da cabeça até os braços, diferente do lenço local que só se destina ao cabelo, no máximo, cabelo e ombros.

${ }^{26}$ A comida Cape Malay [malaia do Cabo] se prepara e aprende nas casas, e particularmente nas redes femininas; em alguns guetos também se vende em porções: mulheres que cozinham comida caseira para vender na vizinhança muçulmana ou cristã. Os salgadinhos Cape Malay são muito mais estendidos e populares ("take away" ou Cape Deli, comidas para levar ou delícias do Cabo) e se encontram em qualquer comércio islâmico nas mediações das estações de trem. Os comércios islâmicos são em geral pintados de vermelho por fora e além das propagandas de coca cola e outras marcas indicam em letras brancas 'Halaal Food' 'Extra Halaal' 'Strictly Halaal' (Comida permitida pelo Alcorão, Extra Permitida/ Estritamente permitida). São operados por pessoas muçulmanas, locais do Paquistão, da Índia, e são frequentados pelos usuários/as de trem, o transporte mais econômico da cidade.

${ }^{27}$ As comunidades islâmicas incluem: a população local, de ancestralidade indiana ou malaia, principalmente; migrantes ou refugiados somalis, paquistaneses, e, em menor escala,
} 
produzem sensorialmente -auditiva, visual e degustativamente - através de intervenções performáticas cotidianizadas, em uma linguagem que comunica com o corpo, ao corpo, desde o corpo (Baaderon, 2015). Comunidades criadas para habitar seções territoriais separadas, cuidadosamente vigiadas, constroem sua globalidade através da religiosidade, e com ela, transpassam as cercas da segregação e isolamento.

O árabe chega no Cabo junto com a população muçulmana de origem malaia e indiana ${ }^{28}$ escravizada pela Companhia Holandesa da Índias Orientais (VOK) há mais de três séculos. No icônico ano de 1994, a comunidade muçulmana celebrou 300 anos de presença do Islão no Cabo, em lembrança da chegada do Sheik Hussuf $^{29}$ em 1694; Hussuf foi um famoso preso político e liderança espiritual, escravizado pela VOK e transportado ao Cabo da Boa Esperança como castigo por sua rebelião anticolonial (BADERON, 2015, p. 8). O islã se praticou em condições de escravidão e prostituição forçada, e foi, portanto, um dos marcadores da diferença entre colonizadores cristãos e escravizados/as, através do qual se constrói e recria uma vida espiritual autônoma, humanificadora. A construção de uma origem reivindicável, memorável, que define a comunidade em termos de resistência a essa associação indesejada com os colonizadores.

Nas montanhas circundantes do Cabo, existem quatro tumbas de líderes islâmicos, que correspondem aos quatro pontos cardiais. Alguns muçulmanos/as se referem a elas como um anel de proteção espiritual. É inevitável remeterse ao culto aos ancestrais em diversas culturas africanas e a forma em que os enterros mediam a relação e o pertencimento da terra e à terra;

provenientes da Tanzânia, Quênia e Uganda. A Cidade do Cabo recebe visitantes temporários do Oriente Médio. Garante circuitos islâmicos: mesquitas, comida Halaal, hospedagens de costumes islâmicos e cursos de inglês em uma cidade com baixa islamofobia.

${ }^{28}$ As populações indiana e malaia conhecia o árabe por motivos religiosos, exclusivamente.

${ }^{29}$ Sheik é uma das formas de denominar aos líderes religiosos no Islã, quem foi treinado para tal feito lê e sabe decorar o Alcorão; estudiosos da religião e da Sharia (lei islâmica). São guias espirituais das comunidades islâmicas e é uma posição permitida apenas para homens. assim como o caráter sagrado das montanhas para a população $\mathrm{Khoi}^{30}$. Nessa linha, as tumbas islâmicas nas montanhas é um inscrição africanizada, africanizante e de criação de origem da comunidade de Cape Malay ${ }^{31}$. Shukran no registro sonoro do Cabo atualiza a longa história de uma resistência a escravatura fincada na planície arenosa de costas a Table Mountain, ícone da cidade colonial (GRUNEBAUM e YAZIR, 2003); de frente ao oceano índico: na memoriosa culinária especiada de uma diáspora asiática.

Dankie, é o agradecimento em Afrikaans, primeira língua da população coloured e indiana. Western Cape é a única província que possui $50 \%$ da população coloured, sendo assim o grupo censitário e linguístico maioritário. Somente $30 \%$ da população é negra, diferente do resto do país onde são maioria; e, em consonância com a média do país, $20 \%$ é branca.

Os descendentes dos colonos holandeses se nomearam de africanos [Afrikaaners] e ao que entendem como "sua" língua de Afrikaans, africano: Nativos, Locais. Nesta lógica, não seria o laço com a metrópole mas sim a origem continental [inventada ${ }^{32}$ ] o que Ihes daria o direito de ocupação. Invocam a África homogeneizando-a (MUDIMBE, 1988): se estabelecem no extremo Sul e se enunciam como continentais. Definir aonde eu pertenço, constitui definir o que me pertence -a terra, e o direito a existir nela. A autodenominação dos colonos holandeses como afrikaners, denota o reclamo do direito a

\footnotetext{
${ }^{30} \mathrm{Em}$ conversas com a liderança Khoi da comunidade de Hout Bay, em ocasão de iniciar um trabalho de Rigth to Know em tal comunidade, acompanhando a ativista Vainola Makan.

${ }^{31}$ A composição dessa população é muito variada, inclui a população do Leste da Africa, o Sudeste da Índia, da Malásia, Khoi e de colonizadores principalmente holandeses. As mulheres escravizadas sofriam estupros sistemáticos por parte de seus "donos"; e desde o momento que chegavam ao porto do Cabo até o momento que eram vendidas eram obrigadas à prostituição, como uma forma de incrementar a riqueza dos escravizadores brancos. Daí que esta população fosse classificada pelos diversos regimes racistas como coloured, termo equivalente a mestiço/a. Uma parte dessa população era islâmica no momento de ser escravizada, outra parte se islamizou na convivência com seus pares islâmicos. Hoje em dia, a maioria da população coloured é cristã. O islã na África do Sul é minoritário, de diáspora e inscreve fortemente sua pertença no continente através do seu papel nas lutas contra a supremacia branca.

32 No sentido que é utilizado pelo Terence Ranger (1983) no capítulo 5 do livro "The Invention of Tradition".
} 
ocupar [apropriar] a África como um todo, em uma visão expansionista. Continente que não era chamado assim pela população africana local, nem reclamado na sua totalidade - pela comunidade coloured $^{33}$, chamada antigamente de Cape Malay, Malaios do Cabo.

Afrikaner em afrikaans refere-se sempre a uma pessoa branca; African, equivalente no inglês, refere-se, no contexto sul-africano, a uma pessoa negra [originaria do continente]. A origem "africana" local da comunidade branca descendente de holandeses é enunciada exclusivamente na língua crioula nascida da experiência escravocrata. No ato de se nomear e autoidentificar continentais unicamente em Afrikaans, parecem admitir que essa africaneidade depende de serem amos da terra [africana] e escravizadores da mão de obra [Negra]. Ainda hoje, dificilmente uma pessoa Negra sul-africana chamaria a uma pessoa branca de africano/a (African, em inglês) ou sul-africano ${ }^{34}$. Essa negação simbólica choca com a gritante realidade: a população branca mora no país há 300 anos. A ocupação de fato e a negação do reconhecimento constroem a complexidade do que Sara Nuttal (2009, p. 1) chamou de entanglement: convivência e dependência forçada.

O afrikaans foi considerado por muito tempo como língua branca ${ }^{35}$ - a língua do opressor no entanto, a maioria de seus falantes são coloured, uma parte dos quais, hoje, a reivindicam como própria, chamando-a de Afrikaaps. Kaap se refere ao nome da região "Cabo"; afri indica proveniente de África. Afrikaaps é um jogo de palavras, literalmente significa a língua africana

\footnotetext{
${ }^{33} \mathrm{O}$ nome atribuído a atual África do Sul pelo Black Conciousness Movement é Azania, nome que é recuperado pelo ativismo negro radical e comunitário. Hoje em dia os chamados territórios "tribais" são neologismos como Zululand, ou referidos pelas divisões administrativas atuais [Eastern Cape, para as terras xhosa] ou antigas [Transkei].

${ }^{34}$ De fato, é relativamente comum que as pessoas Negras questionem a existência no continente de pessoas brancas, e as chamem de settlers ou ocupantes, colonos.

${ }^{35} \mathrm{Em} 1976$ a revolta estudantil de Soweto inaugurou um período insurgente, quando estudantes das escolas primária e secundária repudiaram a obrigatoriedade do ensino em Afrikaans, língua que não dominavam e que não Ihes permitia uma inserção laboral como o inglês. A associação entre a comunidade afrikáner e o apartheid é intensa, daí a associação do afrikáner com a língua do opressor. No entanto, deve ser mencionado que a população branca de origem inglesa também apoiou o regime de supremacia branca.
}

do Cabo: uma língua crioula nascida da experiência colonial ${ }^{36}$ (GQOLA, 2010). Tal referência não omite a especificidade: onde o afrikaans nasceu como língua; e coincide com a região do Cabo onde se concentra a população coloured.

Pumla Gqola (2010) reflete sobre as identidades coloured, e nos lembra a definição de Zimitri Erasmus, quando afirma que ser coloured é uma forma de ser Negro/a. O caráter africano da população coloured, contudo, é o mais contestado (GQOLA, 2010, p. 39). Não são Afrikaans - já que não são brancos - nem Africans, porque não são indígenas. O Estado sulafricano até 1994 construiu grupos juridicamente, alegando uma suposta pureza racial, as comunidades coloured são as mais evidentemente fora do lugar, inclusive quando em todos os casos a pureza é uma ficção. Em termos de construção identitária, não se escuta tão fortemente a reivindicação da ancestralidade Khoi, como tampouco o componente branco; enquanto que a origem asiática é fortemente presente nos nomes, nas comidas, na religião ${ }^{37}$, nas vestimentas e nas genealogias de ancestralidade familiar.

Uma das frases mais corriqueiras nos bairros dos Cape Flats falantes de Afrikaaps para denotar surpresa ou envolvimento emocional com uma situação é "Shame Ma'am" (Shame madam, ou "que vergonha senhora"). Expressão que posiciona a pessoa falante na obrigação de performar a humildade do escravo/a e que atualiza a vergonha; um ethos que Gqola (2010), baseado no artigo de Zoe Wicom, associa à proteção coletiva do trauma da escravidão e à proibição da miscigenação: a vergonha da es-

\footnotetext{
${ }^{36}$ Especialmente da relação entre população colona de origem holandesa e a população de origem malaia, indiana, e africana escravizada. Inclusive o Afrikaans ou o afrikaaps foi escrito no alfabeto árabe seguindo a fonética e, por suposto, sem atender às regras do afrikaans [posteriormente] padronizadas. Uma parte da população malaia do Cabo, devido a sua fé islâmica e à assistência às madrasah ou escolas islâmicas, era letrada em árabe, não no alfabeto romano. Uma enorme maioria dos colonizadores holandeses eram iletrados ou liam apenas a bíblia, sem ter contato com nenhum outro material escrito.

${ }^{37}$ A maioria da população coloured é cristã, sendo o Islã minoritário (10\% da população total); as townships coloured se caracterizam por uma convivência religiosa harmônica, onde o Islã é considerado uma religião pacífica e suas obras sociais respeitadas. A pesar da diferença religiosa compartiIham a mesma língua, culinária, gostos culturais e artísticos.
} 
cravização e humilhação; a participação forçada na colonização do Cabo (como mão de obra e como soldados); a prostituição forçada, os estupros sistemáticos e sua descendência. $\mathrm{O}$ uso cotidiano de Shame não apenas contém a temporalidade da escravidão, como também a experiência generizada da escravidão. Vergonha: sentimento iterativamente invocado, associado à imposição de ser um corpo sexualmente disponível (LEWIS, 2006; GQOLA, 2010; ABRAHAMS, 2003).

Segundo Gabeba Baderoon (2015), o afrikaans foi inicialmente chamado como "língua da cozinha" [Kitchen language]. Esta denominação denota a agência das mulheres escravizadas na sua criação. No entanto, o afrikaans, foi apropriado e higienizado pelos colonizadores, que inscreveram parte de seu nacionalismo e pertencimento à Volk - comunidade - na língua. Hoje, o afrikaans dos Cape Flats é chamado de kitchen afrikaans, como se a planície inteira fosse a cozinha - a área de serviço - da Cidade colonial do Cabo.

Voltando ao Informe Anual 2015 de Mustadafin Foundation, depois de Dankie, agradece em inglês: Thank you. Língua administrativa da cidade, da página web e informativos da organização. O inglês é uma das línguas mais estendidas como segunda língua, e um capital cultural que define o acesso ao mundo do trabalho "de colarinho branco" e a escolarização. No entanto, o inglês e suas formas de se falar codifica também pertencimentos comunitários e exclusões de raça e classe, 'that xhosa accent' (frase derrogatória, com esse sotaque xhosa!), 'my working class English'38 ou as inflexões

\footnotetext{
${ }^{38} \mathrm{Em}$ uma conversa entre jovens negras, uma conta a outra que o jovem Ihe disse que era profissional e ela, sem acreditar, comenta que não pode enganá-la "com esse sotaque xhosa", se referindo a que a universidade é um espaço social onde a forma de falar o inglês é padronizado, higienizado e branqueado. $O$ xhosa accent se refere principalmente à tendência a reduzir as vogais do inglês a 5 sons: a-e-io-u, que são as vogais das línguas banto, como também à presença de marcadores xhosa, como nomear as terceiras pessoas com $U$ antes do nome ou aos lugares acrescentar E no início (prefixos de ser humano e lugar, respectivamente), e a trocar ele/ela, pois não existe tal generização da língua em xhosa. Em uma interação pessoal, uma jovem feminista nos informa como as pessoas ficam entre surpreendidas e petrificadas porque ela é vista como branca e fala um inglês com sotaque da classe trabalhadora, que no Cabo equivale ao sotaque coloured, naqueles sons que
}

afrancesadas dos migrantes do Congo. O inglês chega ao Cabo com a colonização inglesa em 1808 , século XIX, sendo língua oficial no Império, África do Sul independente (1910) e democrática ou pós-apartheid (1994).

Por último, representando várias das áreas onde Mustadafin Foundation trabalha e o caráter africano comunitário da organização, enkosi, o agradecimento em isiXhosa, uma das 9 línguas indígenas oficiais do país. Lembrando que a enorme maioria da população negra na Cidade do Cabo fala isiXhosa, seja como língua materna ou de comunicação ${ }^{39}$.

O isiXhosa pertence ao tronco linguístico banto, e inclui das línguas khoi-san os clicks, fonemas únicos nas línguas mundiais. O xhosa - como o zulu - é a língua da Struggle - luta contra o apartheid. No geral, pessoas brancas ou coloured adultas que estão mais familiarizadas com palavras em xhosa têm relação direta com a luta contra a supremacia branca. Existe todo um vocabulário associado à luta: Amandla! Awethu! (poder ao povo), Hamla Kakhule (despedida aos líderes políticos/as assassinados/as), phantsi (abaixo), phambili (pra frente), o atual hino da África do Sul Nkosi Sikelele Africa, maqabane (camaradas), amakhosikazi (mulheres), entre outras. São um vocabulário politizado, marcado ideológica e racialmente, como se a luta só pudesse ser falada/cantada/saudada em uma língua banto.

Outro conjunto de palavras conhecidas pelo conjunto da população são os marcadores das relações de idade e parentesco: Mama e tata como denominações de respeito, e sisi (irmã), buthi (irmão) em referência a um igual, em termos de idade. A população falante de afrikaaps também utiliza os títulos de parentesco, porém no inglês: ma sista [sister], ma bru [brother], auntie [aunt] ou uncle para indicar respeito (minha irmã, meu irmão, tia ou tio), ou em árabe,

enfatizam os erres, os jotas e as vocais abertas. Sua visualidade e sua sonoridade não se correspondem, criando uma disrupção sensorial com relação as formas hegemônicas de racialização na cidade.

39 Migrantes internos venda, tswana, zulu rapidamente aprendem isiXhosa como forma de comunicação. Assim também é frequente encontrar homens e mulheres de Moçambique, Zimbawe, Somalia ou Etiopia que se comunicam em isiXhosa. 
Baba (pai). As comunidades chamadas de coloured, participam assim, de um ethos que respeita a estrutura de hierarquias etárias, tão tipicamente africanas, mesmo que se desmarque da sua africanização / africaneidade utilizando línguas não banto, o criolo afrikaaps e o inglês. Entre a população xhosa predomina o cristianismo e o culto aos ancestrais, sendo a influência do islã, mínima. Os séculos de segregação impediram que houvesse contatos mais fluidos entre a população coloured e africana, sendo a taxa de conversão pouco significativa. Isso não impede que uma organização como Mustadafin trabalhe em áreas de maioria xhosa, atravessando as fronteiras racializadas, religiosas e linguística sob o lema "a Injustiça é AntiQorânica" (JOHANNESTON, 2015).

As línguas são um aspecto das muitas complexidades de grupos, comunidades, problemáticas e heterogeneidade da população que habita os Cape Flats. O estado colonial, a segregação e o apartheid se deram à tarefa política (Mandami, 2003) de estruturar grupos linguísticos em grupos "raciais", "tribais". Cada grupo linguístico teria estipulado o acesso -maiormente a falta de acesso- a determinados recursos e direitos, especialmente a partir das políticas de retribalização forçada e criação de territórios indígenas "independentes" pelo apartheid durante os anos 60 s e 70 s.

A paisagem gramatical e sonora da cidade vai muito mais além das quatro línguas que analisei aqui. Não falei do amharico nos comércios etíopes, do predomínio do shona das crianças zimbauenses nas escolas da cidade, do somali nos armazéns das townships, do português vocálico de Angola e Moçambique em restaurantes e transporte público, do Lingala e Kiswahili da população refugiada durante a guerra do Congo -RDC, do chinês das lojas de roupa, do Wolof dos desenhadores senegaleses de roupa nas rodoviárias, do urdu dos comerciantes paquistaneses de tecnologia celular, e do chichewa predominante entre os e as trabalhadoras de Malawi. Cidade de polifonias infinitas, só podia ser imaginada como conjuntos separados e internamente homogêneos desde a perspectiva de uma engenharia social racista sofisticada, como foram os regimes de supremacia branca na África do Sul.

Este texto não pretende dar uma visão definitiva, muito menos generalizar as formas de viver os espaços segregados na Cidade do Cabo, senão apenas tensionar o binarismo contido na ideia e classificação da Cidade do Cabo como cidade branca ou inclusive como cidade colonial. Pretende sim, aproximar as/os leitores à paisagem sonora do Cabo, historicamente constituída a partir de um aspecto isolado, como podem ser algumas das línguas faladas. Procura mostrar que nem sequer a absurda e sofisticada engenharia social do urbanismo racista conseguiu reduzir a existência humana as suas categorias. Nem sequer na dolorosa associação classe-raça a hiper-diversidade consegue ser diluída, invisibilizada, desintegrada. A pesar da Cidade do Cabo ser uma das cidades com maior persistência da arquitetura e urbanismo do apartheid e resistir ativamente a mudança desde os encraves de especulação imobiliária e desde as políticas [anti] públicas do governo provincial, existem múltiplas formas de reinventar a vida; formas que "como as plantas que nascem nas fissuras do concreto, sem serem chamadas a existir, simplesmente acontecem" (SANTOS, 2017).

\subsection{Clivagem IV: quebrar a geopolítica do apartheid}

Mustadafin Foundatation - MF, tem seu escritório em Belgravia Road e mais de cinco edifícios 'nas áreas' ou townships. MF opera com descentralização geográfica: é proprietária de edifícios nas áreas onde opera (townships), sendo utilizados para reunião e atividades pela MF e pela comunidade. As integrantes de Mustadafin são mulheres Negras, moradoras das comunidades e, portanto, vão às atividades e trabalho em MF a pé, já que a maioria das tarefas concentra-se nas sedes locais ${ }^{40}$. $\mathrm{O}$ bairro de Atlhone que sedia Mustadafin Fountadion, e foi uma área antigamente classificada como indiana. Atlhone é limítrofe com bairros brancos de Rondenbosh East e é, ao mesmo tempo, a porta de entrada para os Cape Flats. Poucas organiza-

${ }^{40}$ Se deslocar de um gueto até o centro da cidade compreende transitar várias fronteiras. 
ções (ONGs) grandes possuem escritórios nas comunidades onde trabalham ${ }^{41}$, mas sim nas áreas historicamente brancas. Isso tem uma estreita relação com o tipo de pessoas que são empregadas, quem acede aos escritórios, a língua de trabalho, e a geopolítica de distribuição de recursos.

No bairro de Belgravia, Atlhone, todos os comércios vendem comida halaal, especiarias e as roupas adequadas a modéstia e a moda islâmica local; possui instalações de eletricidade, água potável, e se comunica com uma boa parte da cidade: subúrbios do sul (brancos), subúrbios do norte ou Cape Flats e com o centro da cidade, através do ônibus Golden Arrow, trem e kombis (vans). Em Athlone começa a rua Klipfontein, uma das vias de comunicação central das townships e dos distritos industriais (sem contar as estradas, como a N2).

Mustadafin articula a longa tradição de organizações de base da África do Sul, surge desse nível e constrói "para cima" todas as instâncias da organização: facilitadoras, educadoras, direção, finanças, doações. "Me graduei com Mustadafin", disse com orgulho Ghairunisa Johanneston, quando enumera os aprendizados, desde contabilidade a construção de casas. A forma geopolítica que toma a organização faz com que as ativistas de base se profissionalizem ou sejam empregadas sem se afastar territorialmente das suas redes comunitárias. Ao mesmo tempo, diferente de outras ONGs, quase não introduz voluntários/as externos/as às comunidades ou ao país. Promove seu sistema de voluntariados "externos" na University of the Western Cape, onde mais de 90\% dos/as estudantes moram nos Cape Flats e são Negros/as, falam isiXhosa ou Afrikaaps.

Mustadafin atravessa diversas linhas das estruturas racializadas da cidade: por um lado estabelece centros e leva recursos a áreas desfavorecidas, na contracorrente dos olhares locais que estigmatizam os guetos como lugares onde "não se pode fazer nada sem ser roubada". Mulheres de Mustadafin circulam nos guetos

41 Além de MF, conta-se Equal Education, e Sartjiee Bartmaan Women and Children Centre. com camionetes pick up, camionetes para assistência em zonas de desastre e caminhões de mudança para a distribuição de doações. Também transitam a pé e ocupam os espaços públicos vazios das áreas dirigidas por gangsters (Foto 3).

Figura 3: Voluntárias de Mustadafin brincando no parque com crianças que estão integradas ao programa de maternidade social Isibindi, em Manemberg, Cape Flats, Cidade do Cabo.

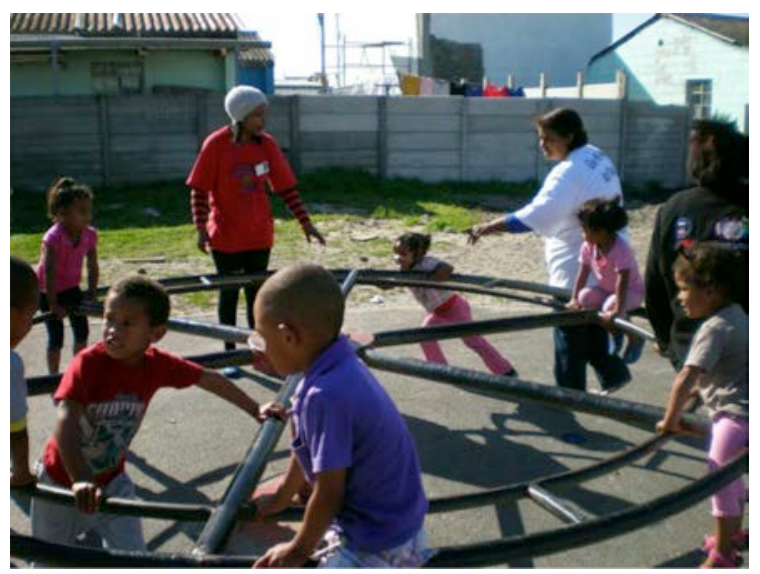

Crédito da foto: Facebook de Mustadafin.

Mustadafin abre um espaço concreto de educação e de trabalho assalariado ou voluntário, onde mulheres Negras, antigamente classificadas como coloured indianas e africanas trabaIham de forma conjunta. Ao mesmo tempo, Mustadafin tem centros comunitários dirigidos por mulheres, edifícios de portas abertas em zonas consideradas de alta periculosidade por questões de violência de rua, enfrentamentos de gangsters, manifestações políticas. MF gera atividades públicas: aulas, eventos, rituais, formaturas dos cursos, oficinas de teatro, dança, etc. Aqueles guetos criados para ser apenas cidades dormitório são reinventados em cada atividade espiritual, educativa ou para o tempo livre que é ali desenvolvida.

MF é um espaço de trabalho para mulheres, e uma porta de acesso para a circulação delas nas comunidades próprias e alheias. $O$ espaço público nas comunidades chamadas de coloured, é chamativamente masculinizado e dominado pela presencia de homens jovens [gangsters] armados. Não é bem visto que as mulheres circulem e espera-se que grande parte das suas vidas aconteça portas adentro (SALO, 2009; 2004). MF provê uma razão para circular: 
participar das atividades, preparar a comida Halaal, organizar as oficinas, distribuir doações; e um motivo respeitável, encaixado dentro das noções locais de decência: a maternidade social. Essa circulação fissura os projetos espaciais do apartheid plasmados na arquitetura da desigualdade, e na generização do espaço público nas townships. O projeto espacial do apartheid não foi apenas racista, mas também sexista: as townships negras contavam principalmente como áreas de moradia para homens jovens solteiros que seriam considerados pelo apartheid como "trabalhadores temporários", ilegalizando a circulação feminina nas áreas urbanas periféricas. Assim o apartheid criou as grandes concentrações de população masculina urbanas africana, ruralizando a população feminina, por lei obrigada a ficar nas áreas rurais, Reservas Nativas. Ainda hoje, as townships são espaços dominados pela hiper-masculinização do âmbito público; própria da historicidade do planejamento racista, que procurava forçar à população negra a ser eternamente temporária no seu próprio pais. O bloqueio da continuidade dos laços familiares contribuiria para esse sentido de alienação.

Mustadafin Foundation gera também circulação de população em sentidos não hegemônicos: leva aos grupos de crianças e jovens de áreas desfavorecidas a acampamentos, à praia, à montanha, a museus, a centros recreativos, entre outras, gerando uma experiência de cidade diferente a que se impõe pelo peso da racialização forçada.

$\mathrm{Na}$ foto da página anterior pode-se ver as muIheres do programa Isibindi ocupando espaços públicos vazios devido a cotidiana presença das gangues. Assim, circular é desafiar o medo, exercer soberania e direito de existir desarmadas, de se apropriarem de espaços que nunca foram imaginados para ser ocupados por muIheres. Promover a brincadeira para crianças que em pouco tempo serão recrutadas por gangues articula também o direito de sonhar com possibilidades diferentes, inclusive quando a iteratividade da tragédia repete-se aparentemente sem limites.

\section{Conclusões}

Para finalizar, me limitarei apenas a sinalizar que o artigo pretendeu expor tanto a estrutura binaria racista da Cidade do Cabo quanto as formas de criação de existência e pertencimento e de comunidades, entanto formas contestatárias de resistir - re-existir - ao peso devastador da cidade colonial; apesar da desumanização cotidiana das desigualdades, a lógica de existir e sobreviver acumulando "em pessoas", se torna uma afirmação micropolítica que rejeita a lógica do apartheid, e a lógica necropolítica masculinizada do gangsterismo. Dentro de tais circunstâncias, organizações de mulheres de base, como Mustadafin Foundation, abrem espaços de contestação, reivindicando o direito a transpor as fronteiras. Na lógica comunitária das redes de mulheres desarmadas, quebra-se também os cercos de isolamento, as clivagens raciais da cidade e as formas de circulação da mesma. Com e apesar das categorias raciais e racializantes, no Cabo das Lutas.

\section{Referências}

ABRAHAMS, Yvette. Colonialism, Disjunctures and Disfunction: Sarah Baartman's Resistance (remix). Agenda, v. 58, 2003.

ALHOURANI, Ala Rabiha. Aesthetics of Muslim public and community formations in Cape Town: observations of an antropologis. Antrophology of Southern Africa, Vol. 38: nro.1-2, 2015.

BADEROON, Gabeba. Regarding Muslims: From Slavery to Post-apartheid. Johannesburgo: Witwatersrand University Press, 2015.

CASTILLEJO CUELLAR, Alejandro. Los Archivos del Dolor. Ensayos sobre la violência y el recuerdo en la Sudáfrica contemporânea. CoIombia: UNIANDES- CESO, 2009.

EDITORIAL. Amandla. Issue. Nro. 39. Ciudad del Cabo, Alternative Information \& Development Centre. Pp. 2, Junio-Julio de 2015.

FANON, Frantz Los condenados de la Tierra. Buenos Aires: Fondo de Cultura Económica, 1983. [1961, 1ra Ed.]

GQOLA, Pumla Dineo. Rape. The South African Nightmare. Cidade do Cabo: MF Books Joburg, 
2015.

What is slavery to me. Poscolonial/ slave memory in post apartheid South Africa. Johannesburg: Wits University Press, 2010.

Brutal inheritances. Echoes, negrophobia and masculinist violence. En Hassim et al. Go Home or Die Here. Violence, Xenophobia and the reinvention of difference in South Africa. Johanesburgo: Wits University Press. 2008.

GRUNEMBAUM The Time after the War: Notes on Historical Encounters Erasures and Postapartheid Pasts. International Journal on Culture and Society 5 Fall, 2012.

GRUNEMBAUM Heidi and YAZIR Henri. Where the Mountain Meets its Shadow: A Conversation of Memory and Identity and Fragmented Belonging in Present-day South Africa. In: Eds. Bo Strath and Ron Robins. Homelands: The Politics of Space and the Poetics of Power. Brussels: Peter Lang, 2003.

HOBSBAWN, Eric e RANGER, Terence. The Invention of Tradition. Cambridge: Cambridge University Press, 1983.

LEWIS, Desiree. Representing African Sexualities. In: TAMALE, Sylvia (Ed.). African Sexualities. A reader. Kenia: Pambazuka Editores, 2011.

Gendered spectacles: new terrains of struggle in South Africa. In: SCHLYTER, Ann. Body Politics and Women Citizens- African Experiences. Stokholm: SIDA Studies. 2009.

MAMDANI, Mahmood. Darle Sentido Histórico a la violencia política en el África. ISTOR, Año IV número 14, 2003.

MARUPTING, Rolf 'I did not expect such a thing to happen'. In HASSIM et al. Go Home or Die Here. Violence, Xenophobia and the reinvention of difference in South Africa. Johanesburgo: Wits University Press, 2008.

MATEBENI, Zethu. TRACKS: Researching Sexualities Walking AbOUT the city of Johannesburg. In TAMALE, Sylvia (ed). African Sexuality Reader. Oxford: Fahamu Books, 2011.
MBEMBE, Achille. Necropolítica, Espanha: Melusina, 2011.

MKHIZE, Nonhlanlha et al. The country we want to live in, Hate crimes and homophobia in the lives of black lesbian South Africans. Cidade do Cabo: HSRC Press, 2010.

MUDIMBE V. Y. The invention of Africa : gnosis, philosophy, and the order of knowledge, Londres: Indiana University Press.,1988

NUTTAL, Sarah. Entanglement. Literary and reflections on post apartheid. Duke University Press/Wits University Press: Johannesburg, 2007.

OLDFIELD, Sophie, Elane SALO and Ann SCHLYTER. [Editorial] Body polítics and the gendered crafting of citizenship. Feminist Africa, 13, Ciudad del Cabo, 2009

OLDFIELD, Sophie e SALO, Elaine. Nurturing researchers, building local knowledge, the body politics project. Feminist Africa, v. 13, diciembre 2009.

RAMPHELE, Mamphela. A bed called home. Life migrant Labour Hostels of Cape Town. Cape Town: David Philip, 1993.

ROSS, Fiona Raw life, new hope: Decency, Housing and Everyday Life in a Post-Apartheid Community. Cape Town: United Nations University Press, 2010.

ROSSOUW, Rehana. What will people say? A novel. África do Sul: Jacana, 2015.

SALO, Elaine. Coconuts do not live in townships, cosmpolitanism and its failures in the urban pheripheries of Cape Town, Feminist Africa, 13, [Body polítics and citizenship], Ciudad del Cabo, 2009.

Respectable Mothers, Tough Men and Good Daughters: Producing Persons in Manenberg Township, unpublished PhD dissertation, Emory University. 2004a.

. Negotiating gender and personhood in the New South Africa: Adolescent women and gangster in Manemberg township on the Cape Flats. Paper presented at the New Social For- 
mations seminars series, Department of Sociology, Stellembosh University, 3 September 2004b.

.Taxi queens and gangsters. Negotiating personhood in a post Apartheid Manemberg. Paper presented at the Centre for African Studies Seminas, University of Cape Town, 2003.

SEGATO Rita. Cuatro Consideraciones sobre la violencia de Género. Conferencia magistral no Coloquio internacional Gênero, ciudadanía y violência. Universidad Autónoma MetropolitanaXochimilco, México Distrito Federal, Maio 2010.

Territorio, soberanía y crímenes de segundo Estado: la escritura en el cuerpo de las mujeres asesinadas en Ciudad Juárez. In: INSTITUTO NACIONAL DE LAS MUJERES (Org.). Ciudad Juárez: de este lado del puente. México: Epikéia, 2004.

STATE OF THE XENOPHOBIA [Feature]. Amandla. Issue. Nro. 39. Cidade do Cabo: Alternative Information \& Development Centre. Junho-Julho 2015.

TAMALE, Sylvia. "Researching and theorising sexualities in Africa". In: TAMALE, Sylvia (Ed.) African sexualities. A reader, Kenia: Pambazuka Editores, 2011.

WALKER, Cherryl, Landmarked. Land Claims and Land Restitution in South Africa. South Africa: Jacana Media, 2008.

WOLPE, Harold. Race, class and the apartheid state, Trenton: Africa World Press, 1990.

\section{Entrevistas}

CLASEEN, Bahia. Parade, Centro, Agosto 2015. Residênte de Sympnhony Road, Delft, Ativista comunitária, integrante do Neighbourhood Watch e de Right to Know Campaign

DEYI, Busisiwe Ncaye. Julho 2015, Observatory. Assistente jurídica e Pesquisadora de Gender Dinamix (ONG enfocada en pessoas trans).

JOHNSTONNE, Ghairunisa. Belgravia, Athlone, Abril, 2015. Diretora e fundadora de Mustadafin
Foundation. MF atende as tonwships de Delft South, Khayelitsha, Mitchell's Plain, Manemberg, Atlantis, entre outras.

MAKAN, Vainola. Belville. Fev e Maio 2015. Organizadora provincial de Right To Know Campaign, foi ativista e empregada do New Women's Movement e de United Women Congress durante os anos 80 .

MATEBENI, Zethu Noviembre 2015, Hidding Campus UCT, Centro, Ciudad del Cabo. Profesora investigadora en el Centre of Humnities, UCT; activista negra y queer, aliada de Free Gender, líder durante los meses iniciales del movimiento estudiantil Rodhes Must Fall, cofundadora del Trans-collective (UCT) y lider de la reciente agrupación Black Academics.

MCELEZILE, Mama Leticia. Gugulethu, ex activista del New Women's Movement e ativista comunitária.

PENKEUR, Wendy. Subúrbios de Stelembosh, Julio, 2015. Integrante de Women Rural Assembly. Lidenraça do Sindicato de Trabalhadoras rurais.

RODHES, Glynis, 13 de Noviembre de 2015, Observatory. Staff de la Western Cape Network Against Violence Against Women [Red contra la violencia contra las mujeres del Western Cape].

SINDIWE E GLORIA, Salt River Community House, Junho 2015, representantes de SADSAWU, sindicato de trabalhadoras domésticas, ex-trabalhadoras domésticas.

SIWISA, Sivu Onesipho y TSHEFU, Sandiswa. Observatory, Noviembre 2015. Activistas LGTBI. Sivu foi organizadora do Khumbulani Pride e do Alternative Inclusive Pride. Tshefu é diretora de cinema e organizadora do evento Kasi to Kasi, o qual reuniu diretoras e diretores dos townships de Cape Town, cujos documentários e produções foram apresentado em Harare Square, Khayelitsha.

\section{Documentários}

MKHOSI, Andi. "Camps Bay Suburb (Alternative Township) Tour". 2015 [Documentario, $12 \mathrm{~min}$. Ciudad del Cabo]. Disponível em: 
https://www.youtube.com/watch?v=8HotFl7LhN 0 . Acceso en 15/01/2016.

MUHOLI, Zanele "We live in Fear", [documental corto, dirigido por Fairfax Zanele Muholi,] 2013. Disponível em: http://mg.co.za/multimedia/201311-26-zanele-muholi-we-live-in-fear. Aceso en 10/01/2016.

NDIFUNA KWASI- Social Justice Coalition (ONG) (2014). "Our Toilets are Dirty". Documentário breve reportando o processo e os resultados de pesquisa sobre os sanitários públicos em Khayelitsha.

\section{Documentos eletrônicos}

CHIGUVARE, Bernard "Operation Fiela, "I saw soldiers moving towards my stall, says trader", 2 July 2015. Disponível em: https://www.groundup.org.za/article/operationfiela-i-saw-soldiers-moving-towards-my-stallsays-trader_3088/. Consultado 15 Julho 2015.

MAREGELE, Bárbara. Most people unsafe in Khayelitsha, Surrey shows. Ciudad del Cabo: Ground Up website, 17 de diciembre de 2015. Disponível em http://groundup.org.za/article/most-people-feelunsafe-khayelitsha-survey-shows_3607. Acesso em 10/02/2016.

MAROMO, Jonisayi The numbers behind Operation Fiela. Mail and Guardian, Sudáfrica. (07 SEP 2015) Disponível em: http://mg.co.za/article/2015-09-07-the-numbersbehind-operation-fiela. Consultado em 15 de novembro de 2015.

MATEBENI Zethu. Rape? Looks more like genocide. Mail\&Guardian, 6 September 2013. Disponível em: http://mg.co.za/article/2013-0906-00-rape-looks-more-like-genocide. Acesso em 3 Agosto de 2015.

MORRIS Mariska. Is Operation Fiela to be Extended? Ground Up, 7 July 2015. Disponível em: http://groundup.org.za/article/operationfiela-be-extended_3101. Acesso em 3 Agosto de 2015.

NKOSI, Lindokuhle Writing the City in a Different Script (June 9, 2015) Disponível em: http://chimurengachronic.co.za/writing-the-cityin-a-different-script/. Acesso em 3 Agosto de 2015.

Police raids accused of being 'state-sponsored xenophobia' 09 mayo, 2015 RDM News Wire. Disponível em: http://www.timeslive.co.za/local/2015/05/09/polic e-raids-accused-of-being-state-sponsoredxenophobia. Acesso em10 de novembro de 2016.

WASHINYIRA, Tariro "Anxiety grows among Zimbabweans while Home Affairs says do not panic". (24 June 2014). Disponível em: http://groundup.org.za/article/anxiety-growsamong-zimbabweans-while-home-affairs-saysdo-not-panic_1921 - sthash.zpt2OwjH.dpu. Acesso em 10 de novembro de 2016.

WILKISON, Kate Do five million immigrants live in South Africa? En Mail \& Guardian, (6 Maio de 2015). Disponível em: http://mg.co.za/article/2015-05-06-do-5-millionimmigrants-live-in-sa. Acesso em 10 de novembro de 2016.

\section{Documentos jurídicos e políticos consulta- dos}

SUDÁFRICA, Immorality Amendment Act No 21, 1950 Disponível em: http://www.disa.ukzn.ac.za/index.php?option=co m_displaydc\&recordID=leg19500512.028.020.0 21. Acesso em 20 de julho 2014.

SUDÁFRICA, Population Registration Act No. 30, 1950. Disponível em http://www.disa.ukzn.ac.za:8080/DC/leg195906 19.028.020.045/leg19590619.028.020.045.pdf. Acesso em 20 de julho 2014.

SUDÁFRICA, Prohibition of Mixed Marriages Act No. 55, 1955. Disponível em http://www.disa.ukzn.ac.za/index.php?option=co m_displaydc\&recordID=leg19490708.028.020.0 55. Acesso em 20 de julho 2014.

SUDÁFRICA,. Pan South African Language Board Act nro 59, 1995. Disponível em https://www.dac.gov.za/sites/default/files/Legisla tions Files/a59-95.pdf. Acesso: 10 nov. de 2016. 
SUDÁFRICA, Lei número 67, 1952, Abolition of Passes and Co-ordination of Documents Act NO 67.

em http://www.disa.ukzn.ac.za/index.php?option=co m_displaydc\& record ID=leg19520711.028.020.067. Acesso em 10 de novembro de 2016.

SUDÁFRICA. Constitution of the Republic of South Africa Act 108 of 1996: promulgada em 16 dezembro de 1996. Disponível em: http://www.justice.gov.za/legislation/acts/1996108.pdf. Acesso em 3 de julho de 2015. 